\title{
Review of Talking Scenography: Conversations between Jarka Burian and Josef Svoboda
}

Talking Scenography: Conversations between Jarka Burian and Josef Svoboda (Scénografie mluví. Hovory Jarky Buriana s Josefem Svobodou). By Barbora DIEGO RIVERA PŘíHODOVÁ. Brno: Masaryk University Press, 2014. 304pp. ISBN 978-80-210-7730-0.

Available at $<$ https://is.muni.cz/obchod/baleni/87383 $>$.

At first glance, it might seem that Josef Svoboda has inspired enough scholarly publications - what might be there to add? Barbora Diego Rivera Př́hodovás edition of Svoboda's talks with Jarka M. Burian, Scénografie mluví (Talking Scenography, 2014) brings great novelty - the perspective of Josef Svoboda (1920-2002), perhaps the greatest twentieth-century scenographer and theatre innovator, on his own work, his working processes, as well as his achievements. Př́ihodová has transcribed and edited recordings made by Jarka $M$. Burian (1927-2005), a North American theatre scholar of Czech descent and indefatigable proponent of Svoboda's work, author of The Scenography of Josef Svoboda (Wesleyan University Press, 1971), Modern Czech Theatre: Reflector and Conscience of a Nation (University of Iowa Press, 2000) or of Leading Creators of Twentieth-Century Czech Theatre (Routledge, 2002). The recordings of Burian's talks with Svoboda have been deposited in the Jarka Burian Collection held at the Jerome Lawrence and Robert E. Lee Theatre Research Institute (Ohio State University).

In editing, commenting and publishing them, Diego Rivera Př́hodová has made available what turn out to be not only somewhat boastful (though well-deserved) and occasionally un-objective expositions, but also an invaluable source of information on concrete technological solutions and inventions. The editor is meticulous in detail and well aware of the limitations, the pros and cons of the material she is handling. In being so precise, she facilitates the ultimate aim of the book: a deeper understanding of Svoboda's production practice, his intentions and his conceptual frameworks. The material is perfectly placed for this: Svoboda's own presentation and explication of his designs is unique and, in its personal testimony, I believe, much more valuable than any refined theorisation. What also comes across from the dialogues is Svoboda's willingness to return repeatedly to his previous work and to discuss it in detail, as well as his ability to place himself and his scenography in the background when the production called for it.

Each of the four main chapters is accompanied by a necessary introduction that helps the readers orientate themselves in the context and the setting of the material. It helps arrange the deluge of motifs and ideas that Svoboda erupts, and also foreshadows the basic facts of the historical and political situation that roots the 
dialogues in concrete coordinates. Diego Rivera Př́hodová also presents and evaluates other theoretical and scholarly work on Josef Svoboda - the works of Denis Bablet (Josef Svoboda. Paris: La Cité, 1970), the above-mentioned study by Jarka Burian, Věra Ptáčkovás Josef Svoboda (Praha: Divadelní ústav, 1983) and Helena Albertovás Josef Svoboda - Scenographer (Praha: Divadelní ústav, 1983). ${ }^{1}$ Finally, the editor provides background information on the individual productions to which the dialogues refer. At the same time, she acknowledges the losses incurred by the impossibility of personal consultation and confrontation.

The first of the four main chapters of the book is dedicated to the end of the socalled 'Golden Sixties' - seen by many as the highlight era of Czech theatre. Svoboda was a crucial part of the scene and the book presents him as an internationally recognised first-class scenographer in the context of the difficult late 1960s that put an end to the politically and socially liberal 'Prague Spring. Svoboda is well aware that his work operates within the continuities of Czech scenography and humbly recognises the towering legacies of the architect, urbanist, cubist and scenographer Vlastislav Hofman (1884-1964) and the avant-garde scenographer and influential teacher František Tröster (1904-1968). Svoboda highlights the importance of general education and the intellectual horizons of a scenographer and also expounds on the collaboration between the scenog-

1 See also Christian M. Billing's detailed review in Czech Stage Art and Stage Design (ed. Christian M. Billing and Pavel Drábek), a special issue of Theatralia 14: 1 (Spring 2011): 270-6. rapher and the stage director in a theatre production. In passing, he mentions his work on the polyecran technique and the Laterna magika project - the world's first multimedia theatre that developed out of Alfréd Radok's and Svoboda's project for the Czechoslovak exhibition at Expo 58 in Brussels. ${ }^{2}$ Svoboda also ruminates on the specificity of scenography as art, on the ideal theatre space, on the complexity of the dramatic arts and the function of scenography in it - all themes that would, in mediation, sound hollow and false; in his own words, they have a weight in being backed up by the overwhelming realisation of these abstract principles. Among his stories are also accounts of his teaching career at the DAMU (Theatre Faculty of the Academy of Performing Arts in Prague) in the 1950s, where he lectured on scenography to students of stage directing; Svoboda speaks of his work with young people as well as of amusing anecdotes of his 'competing' with DAMU's scenography professor Tröster. Finally, he explicates several principles and technologies used in concrete productions - these are wonderful revelations that, to a modern eye, read almost like fairy tales.

The following chapter, 'Pursued by Wagner' (Pronásledován Wagnerem) concentrates on Svoboda's scenography for Wagner productions of the 1970s, mostly abroad, and on his international pedagogical practice. This chapter is a boastful one - is that because Svoboda is making

2 See Eva Stehlíkovás article, ‘The Laterna Magika of Josef Svoboda and Alfréd Radok', in Czech Stage Art and Stage Design (ed. Christian M. Billing and Pavel Drábek), a special issue of Theatralia 14: 1 (Spring 2011): 173-91. 
the recording by himself? Nonetheless, the 1970s were the peak of his career - he was an internationally renowned theatre architect in full strength and his career reached its zenith. He was approached not only by individual stage directors but also by theatre managements as if the Svoboda trademark was a guarantee of production success. In his discussions, he focuses on the 'general' principles in approaching the themes of theatre productions and then provides explanations of the technologies he applied and their usage - some of them, after nearly half a century, sound laughable, while some have not yet been surpassed and testify to his lasting greatness. Svoboda also returns to his teaching career, its next stage - not only his individual approach to students as Professor of Exhibition Curating and Scenography at the School of Applied Arts in Prague (Vysoká škola uměleckopri̊myslová), but also as a guest teacher in the USA, in which country he gave theoretical lectures on contemporary scenography and dramatic space. Svoboda discusses materials and gives many concrete examples of their usage - these are literally treasures he is bringing, compared to our presentday teaching of scenography in the Czech Republic. Svoboda reflects on the quality of his students and their approach to the tasks, on their first scenographic works, and on his teaching practices - he keeps returning to these questions, reconsidering them; his humble approach to the education of future generations is remarkable and any seeming self-centredness of the artist disappears as he commits himself fully to his students.
In the chapter 'An Apology for Scenography' (Obhajoba scénografie), Svoboda talks about his most important artistic partners. He returns to the immediately postWW2, his first major theatre engagement at the May $5^{\text {th }}$ Theatre, in Prague (Divadlo 5. května; later the Smetana Theatre, and today the Prague State Opera). The decisive personalities that contributed crucially to his artistic growth were the opera director and conductor Václav Kašlík (1917-1989); the visionary stage director and co-founder of the Laterna magika Alfréd Radok (1914-1976); and the dramatist, journalist, writer and stage director at the Vinohrady Theatre Jiří Kárnet (1920-2011). Svoboda's recollections are invaluable and unique as personal testimony of his close collaborator Alfréd Radok as well as his friend and collaborator, stage director and actor Miroslav Macháček (1922-1991). Also in this chapter Svoboda expounds on the problems of scenography, making comments on a range of productions done nationally and abroad; again he explicates concrete problems, occasionally disclosing a sheer technological pearl - the ultimate value that this book brings to the scenography practitioner of today.

In the final main chapter 'Post-November 1989 years' (Polistopadová léta), Svoboda looks back on his professional career, as well as reflecting on the new impulses for his scenographic work, such as his collaboration with Giorgio Strehler on a production of Faust, his partnership with Henning Brockhaus on grand operatic productions with a number of technological miracles, or his work with double backdrops, and also with Jarka Burian on the 
school production of Gogol's The Government Inspector that Svoboda approached with the same amount of professional commitment as other productions. Svoboda confesses why he never worked with an assistant - admitting that making technical drawings allowed him to immerse himself again into technical problems, which kept him in immediate contact with the material and the essence of the work. He also finds occasions for memories: he returns back to his beginnings, his encounters with great personalities such as Václav Kašlík, with the influential Modernist and designer František Muzika (1900-1974) or with the avant-garde stage director, theorist, pedagogue as well as ideologist Jindřich Honzl (1894-1953). This series of events were lucky moments for Svoboda that helped him grow and develop as a professional and an artist. Svoboda also reviews life in a totalitarian regime - talking about the accusations of his collaboration with the secret State Police (Státní bezpečnost, StB), about his disillusion, about him being eventually cleared of all charges. He also confesses to doubts about whether he shouldn't rather have emigrated and worked abroad; however, he acknowledges that he always thought of himself as Czech - Svoboda, the Czech Scenographer.

Barbora Diego Rivera Př́hodovás volume ran for the Best Scenographic Pub- lication Prize at the Prague Quadrenniale 2015; and it would certainly deserve great recognition as a key contribution to the discipline. There may have been concrete reasons why the prize wasn't awarded to it: the book's format, the placement of photographs and the overall visual concept perhaps didn't help promote the volume sufficiently. While it has brilliant features - such as the pictograms and keywords and concepts in the margin, which help orientate the reader and provides cross-references within the text - the visual arrangement of the text could be easier on the eye; also the photographs in the margins are somewhat redundant, especially if these are photographs of maquettes that can't offer enough detail in the small size of the illustration.

However, the book more than meets its aims - the deeper understanding of Svoboda's scenographic practice, his intentions and conceptual frameworks. It also occasionally gives us a chance of reaching beyond - it is not only a sum of well-tested experience of working with materials and technologies but also a congenial handbook for a scenographer: it provokes further innovative thinking about scenography and searching for alternative solutions, a legacy not only of Svoboda the Czech Scenographer but also of Svoboda the scenography teacher. As a practitioner I say: Thank you! 